\title{
Erratum to: Comparing the Efficiency of Two Different Extraction Techniques in Removal of Maxillary Third Molars: A Randomized Controlled Trial
}

\author{
Joseph Edward ${ }^{1} \cdot$ Mubarak A. Aziz $^{1}$ Arjun Madhu Usha ${ }^{1} \cdot$ Jyothi K. Narayanan $^{1}$
}

Published online: 25 August 2016

(C) The Association of Oral and Maxillofacial Surgeons of India 2016

\section{Erratum to: J. Maxillofac. Oral Surg.}

\section{DOI 10.1007/s12663-016-0935-1}

The given name of the corresponding author was incorrect in the originally published article. The correct name of the author should read as Arjun Madhu Usha. The original article has been updated accordingly.

The online version of the original article can be found under doi:10.1007/s12663-016-0935-1.

Arjun Madhu Usha

drarjunmu@gmail.com

1 Department of Oral and Maxillo Facial Surgery, Azeezia College of Dental Science and Research, Diamond Hills, Meeyannur, Kollam 691537, India 